Birlesik Dünya Arastırma Global Journal of Business,

\section{BD-CENTER}

Innovasyon ve Yayıneilık Merkezi

\section{Economics and Management: Current Issues}

Volume 10, Issue 3, (2020) 151-160
Global Journal of

Business,Economics and Management: Current Issues

\title{
Scientific research fields in accounting of municipal sector entities
}

Beata Sadowska a ${ }^{1}$, University of Szczecin, 70-453, Aleja Papieża Jana Pawła II 22A, Szczecin, Poland https://orcid.org/0000-0001-6383-3972

Magdalena Wójcik-Jurkiewicz ${ }^{b}$, Cracow University of Economics, Department of Accounting College of Management and Quality Sciences Academic, Poland https://orcid.org/0000-0001-7177-2540

\section{Suggested Citation:}

Sadowska, B., \& Wójcik-Jurkiewicz, M. (2020). Scientific research fields in accounting of municipal sector entities. Global Journal of Business, Economics and Management: Current Issues. 10(3), 151-160. https://doi.org/10.18844/gibem.v10i3.4683

Received March 21, 2020; revised May 15, 2020; accepted November 05, 2020.

Selection and peer review under responsibility of Prof. Dr. Cetin Bektas, Gaziosmanpasa University, Turkey. (C)2020 Birlesik Dunya Yenilik Arastirma ve Yayincilik Merkezi. All rights reserved.

\section{Abstract}

Accounting in the municipal sector is an important and up-to-date issue. The objective of the article is to analyze and present theoretical determinants of accounting in the municipal sector as an industry system, and to present scientific research fields in budget accounting and corporate accounting in business entities which provide municipal services. The research was based on articles published in the Research Papers of Wrocław University of Economics in 2016. To achieve the objective formulated in such a way, the analysis of literature and logical inference were adopted as research methods. The literature review contributed to presenting new scientific research fields worth investigating and analyzing, in the municipal sector accounting.

Keywords: accounting, budget accounting, municipal sector, scientific research

* ADDRESS FOR CORRESPONDENCE: Beata Sadowska, University of Szczecin, 70-453, Aleja Papieża Jana Pawła II 22A, Szczecin, Poland

E-mail address: beata.sadowska@wzieu.pl 


\section{Introduction}

Accounting in entities of the municipal sector is an important and up-to-date issue (Otrusinova \& Kulleova, 2019; Dollery et al, 2020; Edmonds et al., 2020). The accounting system as a basic information system that every organization adopts is constantly developing, evolving, and adapting its solutions to changes taking place in business entities (Comandaru et al., 2020). The municipal sector entities are specific business entities whose main task is to achieve public utility objectives, that is providing municipal goods and services to a local community residing in each commune.

In their research, Dollery et al, (2020) explained that cash accounting, accrual and modified accrual accounting are the bases of accounting for public sector. With recent developments, most countries have adopted the full accrual accounting method as the basis for their accounting process. According to Dollery et al. (2020), the use of this basis of accounting in municipalities, helps the management to take decisions that are more effective in the long run.

Otrusinova \& Kulleova, (2019) also conducted a similar research in modern accounting for municipal sectors. In their research titled 'Liquidity values in municipal accounting in the Czech Republic', they explained liquidity management and suggested best methods for municipal liquidation. The research concluded that to have an accounting system that works, municipals must determine what their assets and liabilities should be, based on the conditions of that municipality. Hassan et al. (2018) and Savaşan et al. (2018) supported this assertion in a similar study, when they explained that every community must adopt principles that work best for the community.

The objective of the article is to analyze and present theoretical determinants of accounting in the municipal sector as an industry system, and to present scientific research fields in budget accounting. The thesis of the study is as follows: "Scientific research fields related to accounting of the municipal sector entities are subject to a lot of research and investigation of modern representatives of science".

The aim of the research on the accounting system in the municipal sector is to reflect economic practice as well as establish the theoretical framework for practice. Accounting in the municipal sector concerns:

- identification of data pertaining to events and units being subject to observation and their documentation,

- $\quad$ transformation of data using processing methods and procedures typical of the accounting system,

- application of specialist recording devices,

- $\quad$ presentation and provision of financial and non-financial information.

\section{Methodology}

This research was a literature review. The research collected data from articles published in the Research Papers of Wrocław University of Economics in 2016. The sampling method was purposive because the data was selected from the source that the researcher deems fit for providing resource to facilitate this study. To achieve the objective formulated in such a way, the analysis of literature and logical inference were adopted as research methods. The literature review contributed to presenting new scientific research fields worth investigating and analyzing, related to the municipal sector accounting.

Nowadays, three research approaches are used in terms of accounting in the world of science: mainstream research, interpretation research and critical research (Uzunboylu \& Genc, 2017).

In 2016, Wydawnictwo Uniwersytetu Ekonomicznego we Wrocławiu [Publishing House of Wroclaw University of Economics] published 45 issues of the Research Papers, from the issue no. 415 to the issue no. 460, in which authors published the total of 1,219 scientific papers. On average, each issue includes 27 studies. These papers included scientific articles concerning, among other things:

- Accounting and controlling,

- Theories of accounting, reporting and financial analysis,

- Finance and accounting for sustainable development, 
- Accounting - macroeconomic policy and globalization,

- Cost account, management accounting and controlling,

- Cost and performance management.

\section{Findings and discussion}

\subsection{Characteristics of the municipal sector - municipal management in Poland}

The fundamental framework for the functioning of municipal management in Poland is mainly stipulated in tasks of local authorities whose scope is defined in the Constitution of the Republic of Poland (1997) and:

- Act on Municipal Management (1996),

- Act on Commune Self-Government (1990),

- Act on Powiat Self-Government (1995),

- Act on Voivodship Self-Government (1998).

Municipal management means community management. Issues of municipal management, or to be precise, of a society making up a community in each territory are also referred to in the European Charter of Local Self-Government (1985). Satola, (2018) and the research of Horton \& Farnham, (2015) emphasizes that local governments execute public duties not reserved by the constitution or acts on public authorities. The commune is the basic unit of local government (Felekoglu, 2018; Napitupulu, 2018). The constitutional provisions concerning municipal management are stipulated in Art. 166. According to it, public duties aimed at satisfying the needs of a self-governing community (including duties in terms of municipal management) are performed by units of local government as their direct responsibility.

Detailed and statutory provisions concerning municipal management executed by local government units stipulated in the Constitutions are regulated by the Act of 20 December 1996 on Municipal Management, which is hereinafter referred to as "MMA". According to Art. 1.1 of this Act, municipal management in Poland involves performing direct duties by local government units (communes) to satisfy collective needs of a self-governing community. Municipal management involves mainly public utility tasks which aims to satisfy collective needs of people regularly by providing commonly available services (AY, 2020; Bezat-Jarzebowska et al, 2018).

The Art. 2 of the Act stipulates that municipal management can be done by local authority bodies, especially in the form of budgetary units, budgetary divisions or commercial companies and partnerships. The scope of the Act includes municipal management of communes, districts, and voivodships. In accordance with Art. 7.1 of the Act on Commune Self-Government, the direct responsibility of a commune is satisfying collective needs of a community. As Satola, L. (2018) and Sadowska (2012) indicate, this responsibility is treated as municipal services which involve the following issues:

- spatial order, real estate management, environmental and nature protection as well as water management,

- communal roads, streets, bridges, squares, and road traffic organization,

- waterworks and water supply, water sewage system, municipal sewage treatment, cleanliness, and order as well as sanitary system equipment, landfills and municipal waste treatment, electric power, heat, and gas supply,

- telecommunication activities,

- local public transport,

- health protection,

- social welfare, including institutional care centers,

- support for a family and foster care system,

- local residential construction, 
- public education,

- culture, including local libraries and other culture institutions as well as protection and maintenance of objects of cultural heritage,

- physical culture and tourism, including recreational areas and sports equipment,

- outdoor and indoor markets,

- local green areas and tree stands,

- communal cemeteries,

- public order and security of citizens as well as fire and flood protection, including equipment and maintenance of a flood protection storehouse,

- maintenance of communal public utility buildings and devices as well as administrative buildings,

- pro-family policy, including providing pregnant women with social and medical care as well as legal assistance.

In accordance with Art. 7.2 of the Act on Commune Self-Government, the commune direct responsibility is basically divided into obligatory and optional. The objective of this regulation is to ensure that the society receives public services at the basic level. The legislator does not formulate or impose a catalogue of obligatory tasks. The municipal sector is a part of national economy and concerns a given commune and its community, whereas municipal management aims at satisfying people's needs in terms of health protection, social welfare, public education, culture, provision of municipal services, etc.

\subsection{Accounting in the municipal sector - legal and organizational aspects}

One should agree with Malinowska (2013) and Haouam (2020) that the objective of modern accounting is to analyze and provide reliable and true data on an economic and financial situation of an organization, so it should not be limited only to recording and controlling tasks. Accounting should be treated as an organized system of information flow whose main task is to provide various information for the purposes of business entity management. The introduction and application of the accounting policy and principles in organizations are determined by many factors. These are legal norms, regulations and rules included in the Polish Accounting Act (1994).

According to Chłapek et al. (2018), accounting is a universal, flexible, subject information and control system. The American Accounting Association in 1966 defined accounting as a process of identification, measurement and provision of financial information enabling formulating economic assessments which help users of such information in taking decisions (Christensen, 2018). As Ignatowski \& Wójcik-Jurkiewicz (2016) rightly observe, one of the greatest challenges of accounting which business entities face nowadays is measuring and reporting information on the extent to which organization's objectives have been executed.

The Accounting Act (1994) stipulates accounting principles and rules for providing bookkeeping services. The provisions of the Accounting Act are applied, among other things, to:

- commercial companies and partnerships,

- natural persons, partnerships, limited liability partnerships,

- communes, districts, and voivodships, as well as:

$\checkmark$ national, communal, district and voivodship budgetary units,

$\checkmark$ communal, district and voivodship budgetary divisions.

In economic practice, enterprises are classified according to various criteria. Some factors for applying the accounting system are legal and organizational aspects of a given entity. Neither the size of a given organization, nor the type of business activities unambiguously determines whether the accounting system is used in an enterprise. As Karwot \& Ober (2019) indicates, diverse institutional solutions and legal and organizational forms of business activities are used in the municipal sector. Specific decisions should be adjusted to local needs, possibilities, and the character of activities. There 
is not one model of structural solutions as there are various conditions, concepts, and practical activities in local authority bodies.

It should be highlighted that municipal services in Poland are provided mainly by limited liability companies and budgetary divisions. These forms of organization of communal services are determined by accounting systems in given organizations. Limited liability companies keep the books based on the Accounting Act, whereas budgetary divisions as entities of the public finance sector additionally follow ordinances of the Minister of Finance on accounting principles.

A budgetary division is an organizational unit of the public finance sector which conducts tasks against payment and covers costs of its activities from own revenues. A budgetary division is affiliated with a parent entity through net budgeting method which means that in the event of loss it is covered from superior entity's funds. However, in the event of profit, a budgetary division pays it in full to the budget. Gwizdała (2018) add that a budgetary division is "... a unit which does not have legal personality and does not execute its own pricing policy. Financial economy of a budgetary division is based on an annual plan and its financial economy is executed in accordance with the Public Finance Law...". Legal regulations precisely indicate when communes can establish, transform, and liquidate budgetary divisions, what services they can provide and how activities conducted as part of a budgetary division should be organized and funded. The characterized organizational and legal form is established to conduct specific tasks against payment, that is why one of revenue sources of a budgetary division is own revenues.

Commercial companies are joint-stock company and limited liability company. A joint stock company is the oldest form of a company as it already started to develop in the 19th century. It is a form which is particularly beneficial to large enterprises in the public service sector, however, it is rarely used. The market observations and analysis of literature show that limited liability companies dominate in the municipal sector. Local authority bodies can form commercial companies and partnerships as well as enter the existing ones. One should agree with Gałuszka (2009) that a commune can form commercial companies and partnerships provided that the following two conditions are met at the same time:

- there are unsatisfied needs of a local community on the local market,

- unemployment in a commune considerably and negatively influences the level of community's life and undertaking other activities have not led to economic activation, especially to the revival of the local market.

Commercial companies and partnerships that currently function, mainly limited liability companies, have a lot of autonomy in terms of developing the financial policy, what makes them privileged in comparison with budgetary divisions.

Accounting as a field dealing with defining and presenting phenomena and processes occurring in business entities is subject to legal regulations. A fundamental legal act regulating the principles of accounting in Poland is the Accounting Act. The entity's accounting system includes:

- the adopted accounting principles (policy),

- keeping the books based on accounting documents,

- verifying the real situation of assets and liabilities regularly (inventory),

- valuating assets and liabilities and establishing the financial result,

- preparing financial statements,

- collecting and storing accounting documents.

It should be emphasized that the Accounting Act is universal as fundamental assumptions and principles stipulated in it concern all organizations which are obliged to comply with it. Nevertheless, in terms of issues or legal provisions pertaining to a specific group of recipients (public sector units), the Act refers them to relevant regulations. 


\subsection{Accounting in the municipal sector - fields of research}

Accounting in the municipal sector is executed depending on the organization of municipal services. Municipal services can be provided by commercial companies and partnerships or budgetary divisions or units (the budgetary accounting system, industry accounting). Commercial companies and partnerships keep the books based on the Accounting Act and follow the accounting principles addressed to enterprises (corporate accounting). Currently, municipal services are mainly provided by limited liability companies. These entities are not obliged to follow other legal acts or regulations as the organizational units of the public finance sector (for example, budgetary divisions have industry accounting).

One should agree with Winiarska \& Kazarczuk-Kozak (2011) that a fundamental regulation governing budgetary accounting is the Public Finance Law (2009) and the Ordinance of the Minister of Finance on the detailed accounting principles and charts of accounts for the state budget, budgets of local authority bodies as well as particular bodies of the public finance sector (2010). According to Leksykon Rachunkowości (1996) as quoted by Walińska et al., (2018), budgetary accounting can be defined as the accounting of a government, local authorities and budgetary institutions whose objective is to provide information on the implementation of the budget as well as on financial plans and the economic situation of budgetary units and other organizational and legal forms of the public finance sector units.

Nowadays, organizations have financial accounting, management accounting, controlling, cost accounts and tax accounting to provide information necessary for the purpose of organizational unit management as well as the fulfilment of information needs of various groups of users/stakeholders (Tasar, 2019).

Scientific research on accounting is selectively described in literature due to the scale of issues it encompasses and great methodological diversity. As Ediraras et al. (2017) rightly observes, a general theory of accounting has not been yet developed, however, there is a set of various theories. Moreover, there are also different approaches to developing accounting theories: tax, legal, ethical, economic, behavioural and structural theories which have been adopted to coin terms connected with accounting and have contributed to the development and assessment of accounting principles, methods and procedures.

The research findings, that is articles directly and indirectly concerning the municipal sector and the accounting system in this sector are presented in Table 1.

Table 1. Scientific research fields in accounting of the municipal sector entities

\begin{tabular}{|c|c|c|c|}
\hline Article Title & $\begin{array}{c}\text { Research } \\
\text { Papers No. }\end{array}$ & Pages & $\mathrm{D} / \mathrm{I}^{*}$ \\
\hline $\begin{array}{l}\text { 1. Rzeczowo-ekologiczne efekty realizacji krajowego Programu } \\
\text { Oczyszczania Ścieków Komunalnych [Material and ecological } \\
\text { aspects of the implementation of the national Program of the } \\
\text { Municipal Wasterwater Treatment] }\end{array}$ & 418 & $156-166$ & $P$ \\
\hline $\begin{array}{l}\text { 2. Poziom realizacji gospodarki odpadami na obszarach } \\
\text { atrakcyjnych turystycznie [The level of waste management } \\
\text { development in the tourist attractive areas] }\end{array}$ & 418 & $311-317$ & $P$ \\
\hline $\begin{array}{l}\text { 3. Analiza przypadków wdrożeń zrównoważonej karty wyników } \\
\text { w jednostkach samorządu terytorialnego [The analysis of the } \\
\text { balanced scorecard implementation in the local government } \\
\text { units] }\end{array}$ & 424 & $164-172$ & B \\
\hline $\begin{array}{l}\text { 4. Rozwój pracowników w JST w ramach środków Europejskiego } \\
\text { Funduszu Społecznego - wyniki wstępnych badań empirycznych } \\
\text { [Employee development in local government units eithin the } \\
\text { European Social Fund in Poland - preliminary research findings] }\end{array}$ & 429 & $290-306$ & $\mathrm{P}$ \\
\hline
\end{tabular}


5. Uwarunkowania przestrzennego zróżnicowania selektywnej zbiórki odpadów komunalnych [Conditions of spatial diversity of separate collection of municipal waste]

6. Koszty środowiskowe w sektorze wodno-kanalizacyjnym [Environmental costs in water and sewage sector]

7. Działalność gminy w Niemczech i w Polsce - uwarunkowania prawne, organizacyjne i finansowe [Activities of municipalities in Germany and Poland - legal, organizational, and financial factors]

8. Obszary ryzyka prowadzenia działalności przedsiębiorstw ciepłowniczych [Areas of risk in heating companies]

9. Systemy typu Data Discovery w praktyce funkcjonowania przedsiębiorstwa komunalnego [Data Discovery systems in practice of functioning of municipal enterprise]

10. Identyfikacja i wyodrębnianie przychodów i kosztów przewozów o charakterze użyteczności publicznej w przedsiębiorstwach transportu samochodowego [Identification and distinction of revenues and costs of public utility transport in bus enterprises]

11. Ośrodki odpowiedzialności i miejsca powstawania kosztów w przedsiębiorstwach wodociągowo-kanalizacyjnych

[Responsibility centers and cost centers in water and sewerage companies]

12. Logistyka odzysku - optymalizacja przepływów w systemie gospodarki komunalnej [Reverse logistics - optimization of flows in the system of waste management]

13.Optymalizacja tras zbiórki odpadów komunalnych na przykładzie MPO Kraków [Optimization of municipal solid waste collection and transportation routes on the example of MPO Cracow]

14. Analiza skuteczności i zrównoważenia polskiego systemu gospodarki odpadami komunalnymi [Analysis of the effectiveness and sustainability of the Polish municipal waste management system]

15. Ocena wskaźnikowa inwestycji infrastruktury wodnokanalizacyjnej w aspekcie zrównoważonego rozwoju [Evaluation of investment ratio water supply and sewerage infrastructure in the context of sustainable development]

16. Ekonomiczne i techniczne uwarunkowania procesów spalania odpadów komunalnych [Economic and technical determinants of municipal solid waste incineration]

17. Nakłady inwestycyjne na gospodarkę odpadami [Capital expenditure on waste management]
432

$129-137$

436

$219-230$

B

393-404

$\mathrm{P}$

$411-419$

$P$

$175-183$

B

$203-212$

B

70-82

P

446

$83-92$

P

454

$31-44$

P

454

$79-91$

B

454

$174-185$

P

454

* $D / I$ - direct/indirect reference to the municipal sector, the field of municipal services

Source: own work

In 2016, in the Research Papers of Wrocław University of Economics authors published the total of 17 articles and 6 of them referred directly to the research on the accounting system in the municipal sector.

The results prove that most researchers were not interested in the topic of accounting in municipal sector of Poland. This is because, majority of the researchers of the Wrocław University of Economics made no reference to accounting in their research work. Therefore, the thesis of this research was negatively verified. 


\section{Conclusion}

The theory of social research aims mainly at discovering regularities in the social life. A part of social research and theories is economics which concerns the aspects connected with how people deal with limited resources. Resources are reflected in the accounting systems in which they are presented quantitatively and qualitatively.

Economic phenomena, events, operations, processes, and activities which take place in an organization while conducting its business activities are registered in the accounting systems. The role of these system is to collect, record, measure, and report financial and non-financial information to the interested stakeholders. As Lulek (2017) indicates, "theoreticians emphasize the role of accounting in creating information on the activities of a business entity. If the information system of an enterprise in a broad sense is considered, the information system of accounting will be one of its most crucial elements".

The objective of the article was to analyze and present theoretical determinants of accounting in the municipal sector as an industry system, and to present scientific research fields in budget accounting. The research was based on articles published in the Research Papers of Wrocław University of Economics in 2016. To achieve the objective formulated in such a way, the analysis of literature and logical inference were adopted as research methods.

The thesis of the study which was "Scientific research fields related to accounting of the municipal sector entities are subject to a lot of research and investigation of modern representatives of science" was negatively verified. Accounting undertaken by commercial companies and partnerships of local authority bodies as well as budgetary accounting (industry) are not an interesting field of research for scientists. Therefore, the following questions should be posed:

1. Why does the world of science deal with the issues of the municipal sector so rarely?

2. What are the reasons that scientists in Poland do not conduct research on accounting in the municipal sector?

\section{Recommendation}

The literature review and the negatively verified thesis of the article contributed to presenting scientific research fields related to the municipal sector accounting worth investigating and analyzing. In the author's opinion, the following dilemmas of the accounting system are worth considering:

1. Relationships between an organization's strategy and the accounting system, including innovative (management) accounting tools.

2. Role and significance of information generated by the accounting system as well as needs and expectations of various groups of stakeholders (investors, ecologists, society).

3. The accounting system of the municipal sector and the measurement theory (financial and non-financial measurement).

4. The accounting system of the municipal sector and the concept of sustainable development as well as CSR.

The dilemmas of the accounting system in the municipal sector should contribute to further indepth scientific research.

\section{References:}

Act of 20 December 1996 on Municipal Management. Journal of Laws of 1997, No. 9, item 43, as amended.

Accounting Act of 29 September 1994. Journal of Laws of 2017, item 1089.

Act on Commune Self-Government of 8 March 1990. Journal of Laws of 1990, No. 16, item 95, as amended.

Act on Powiat Self-Government of 5 June 1995. Journal of Laws of 2001, No. 142, item 1592.

Act on Voivodship Self-government of 5 June 1998. Journal of Laws of 2001, No. 142, item 1590, as amended. 
Sadowska, B., \& Wójcik-Jurkiewicz, M. (2020). Scientific research fields in accounting of municipal sector entities. Global Journal of Business, Economics and Management: Current Issues. 10(3), 151-160. https://doi.org/10.18844/gjbem.v10i3.4683

Accounting Act of 29 September 1994. Journal of Laws of 2017, item 1089.

Act of 20 December 1996 on Municipal Management. Journal of Laws of 1997, No. 9, item 43, as amended.

Act on Commune Self-Government of 8 March 1990. Journal of Laws of 1990, No. 16, item 95, as amended.

Act on Powiat Self-Government of 5 June 1995. Journal of Laws of 2001, No. 142, item 1592.

Act on Voivodship Self-government of 5 June 1998. Journal of Laws of 2001, No. 142, item 1590, as amended.

AY, G. (2020). Evaluation of views regarding pharmacy information management systems implementation and systemic issues in community pharmacies. International Journal of Emerging Trends in Health Sciences, 4(1), 68-76. Retrieved from https://un-pub.eu/ojs/index.php/ijeths/article/view/4522

Bezat-Jarzebowska, A., Rembisz, W., \& Sielska, A. (2018). Model of public choice and political rent. International Journal of New Trends in Social Sciences, 2(2), 49-57. https://doi.org/10.18844/ijntss.v2i2.3816

Chłapek, K., Krajewska, S., \& Jonas, K. (2018). Conditions for changes in the programme and teaching methodology of accounting in terms of integrated reporting challenges - The prospect of the academic teacher. New Trends and Issues Proceedings on Humanities and Social Sciences, 5(3), 183-192. https://doi.org/10.18844/prosoc.v5i3.3923

Christensen, J. (2018). Accounting in 2036: A Learned Profession: Part II: A Learned Research and Education Environment. The Accounting Review, 93(6), 387-390.

Comandaru, A.-M., Stanescu, S.-G., Toma, C., \& Păduraru, A. (2020). Another image of accounting - creative accounting. Global Journal of Business, Economics and Management: Current Issues, 10(2), 100 - 110. https://doi.org/10.18844/gjbem.v10i2.4695

Constitution of the Republic of Poland of 2nd April 1997. Journal of Laws of 1997, No. 78, item 483.

Dollery, B., Kitchen, H., McMillan, M., \& Shah, A. (2020). Municipal Budgeting and Accounting. In Local Public, Fiscal and Financial Governance (pp. 91-121). Palgrave Macmillan, Cham.

Ediraras, D., Putra, A., \& Purtiningrum, S. (2017). IFRS integration into accounting curriculum: Undergraduate accounting students' perceptions in JakartaAbstract. Global Journal of Sociology: Current Issues, 7(1), 2-8. https://doi.org/10.18844/gjs.v7i1.2363

Edmonds, C. T., Leece, R. D., Vermeer, B. Y., \& Vermeer, T. E. (2020). The Information Value of Qualified and Adverse Audit Reports: Evidence from the Municipal Sector. Auditing: A Journal of Practice \& Theory, 39(1), 21-41.

Felekoglu, H. (2018). The relation of the urban centre (city) and movie theatres as public spaces in Ankara. Global Journal of Arts Education, 8(1), 08-16. https://doi.org/10.18844/gjae.v8i1.3252

Gałuszka K. 2009. Spółki handlowe jako forma współpracy jednostek samorządu terytorialnego [Commercial companies and partnerships as a form of cooperation of local government bodies]. In Samorząd terytorialny w zintegrowanej Europie [Local government in integrated Europe]. Eds. B. Filipiak, A. Szewczuk. Wydawnictwo Naukowe Uniwersytetu Szczecińskiego. Szczecin, p.131

Gwizdała, J. (2018). Risk in the investment activity of local-government units in Poland. THE CHALLENGES OF LOCAL GOVERNMENT FINANCING IN THE LIGHT OF EUROPEAN UNION REGIONAL POLICY, 193.

Haouam, D. (2020). IT governance impact on financial reporting quality using COBIT framework. Global Journal of Computer Sciences: Theory and Research, 10(1), 1-10. https://doi.org/10.18844/gics.v10i1.4143

Hassan, H., Abu Bakar, A. Y., \& Amat, S. (2018). Psynnova IBMT module as an intervention against changes in the behaviour of low-performing civil servants in Malaysia. Global Journal of Guidance and Counseling in Schools: Current Perspectives, 8(1), 17-27. https://doi.org/10.18844/gigc.v8i1.3574

Horton, S., \& Farnham, D. (2015). Management of Public Services: Legacies, Impact and Prospects. Public Management in Britain, 247.

Ignatowski R., Wójcik-Jurkiewicz M. 2016. Raportowanie spółek w zakresie społecznie odpowiedzialnego biznesu [Reporting of companies in terms of corporate social responsibility]. In Instrumenty polityki społecznej [Social policy instruments]. Eds. G. Ignatowski, Ł. Sułkowski, Z. Dobrowolski, Difin, Warsaw, pp. 130131. 
Karwot, J., \& Ober, J. (2019). Manager in the municipal sector-employment conditions? Organizacja i Zarządzanie: kwartalnik naukowy.

Leksykon rachunkowości [Lexicon of accounting]. 1996. Ed. E. Nowak. PWN. Warsaw, p. 175.

Lulek A. 2017. Od przeszłości do przyszłości - ewolucja rachunkowości i jej pojęcia [From past to future - the evolution of accounting and its concept]. In Dylematy i perspektywy rozwoju finansów i rachunkowości [Dilemmas and perspectives of the development of finance and accounting]. Eds. P. Szczypa, A. Zimny, Wydawnictwo Państwowej Wyższej Szkoły Zawodowej in Konin, Konin 2017, pp. 94-95.

Malinowska M. 2013. System rachunkowości w jednostkach nieprowadzących działalności gospodarczej [Accounting system in entities not conducting business activities]. In Rachunkowość, finanse, audyt i kontrola. Studium przypadków sektora publicznego i prywatnego [Accounting, finance, audit, and control. Case studies of the public and private sectors]. Eds. T. Gabrusewicz, K. Marchewka-Bartkowiak, M. Wiśniewski. CeDeWu. Warsaw, p. 117.

Napitupulu, L. (2018). People's Perception Towards Immigrants Based on Acceptance in Pekanbaru (Riau Province). Global Journal of Psychology Research: New Trends and Issues, 8(2), 88-96. https://doi.org/10.18844/gipr.v8i2.3491

Otrusinova, M., \& Kulleova, A. (2019). Liquidity values in municipal accounting in the Czech Republic. Journal of Competitiveness.

Public Finance Law of 27 August 2009. Journal of Laws of 2009, No. 157, item 1240, as amended.

Sadowska, B. (2012). A budgetary establishment and a commercial law company - theoretical aspects of organizing and financing municipal housing resources in municipalities. Scientific Journals of the University of Szczecin. Economic Problems of Services, (100 Financial economy of local government units in relation to regional development processes: 8th Local Government Forum), 195-207.

Satola, L. (2018). Differentiation of charges for local public services on the example of water supply and sewage disposal services. Scientific Annals of the Association of Agricultural and Agribusiness Economists, 20 (6). Hendriksen E.A., van Breda M.F. 2002. Accounting Theory. Wydawnictwo Naukowe PWN. Warsaw, pp. 23-44.

Savaşan, A., Yalvaç, M., Uzunboylu, H., \& Tuncel, E. (2018). The attitudes of education, tourism, and health sector managers in Northern Cyprus towards Education on Health Tourism. Quality \& Quantity, 52(1), 285303.

Tasar, H. (2019). Financing from Demand-Side in Education. Contemporary Educational Researches Journal, 9(1), 14-19. https://doi.org/10.18844/cerj.v9i1.4019

Uzunboylu, H., \& Genc, Z. (2017). Analysis of documents published in Scopus database on foreign language learning through mobile learning: a content analysis. Profile Issues in TeachersProfessional Development, 19, 99-107.

Walińska, E., Walczak, M., Szychta, A., Michalak, J., \& Gad, J. (2018). Book of the 70th anniversary of the Accounting Department of the University of Lodz. People and their achievements. Publishing House of the University of Lodz.

Winiarska K., Kaczurak-Kozak M. 2011. Rachunkowość budżetowa [Budgetary accounting]. Wydawnictwo Wolters Kluwer Polska Sp. z o.o., Warsaw, p. 11. 